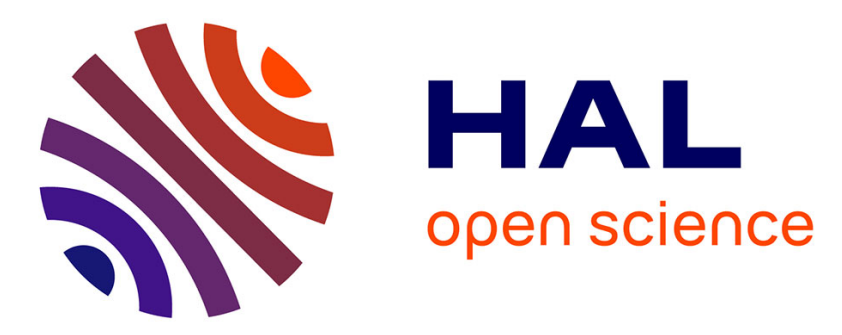

\title{
Relationships among predatory fish, sea urchins and barrens in Mediterranean rocky reefs across a latitudinal gradient \\ P. Guidetti, J. Dulčić
}

\section{> To cite this version:}

P. Guidetti, J. Dulčić. Relationships among predatory fish, sea urchins and barrens in Mediterranean rocky reefs across a latitudinal gradient. Marine Environmental Research, 2007, 63 (2), pp.168. 10.1016/j.marenvres.2006.08.002 . hal-00501815

\section{HAL Id: hal-00501815 https://hal.science/hal-00501815}

Submitted on 12 Jul 2010

HAL is a multi-disciplinary open access archive for the deposit and dissemination of scientific research documents, whether they are published or not. The documents may come from teaching and research institutions in France or abroad, or from public or private research centers.
L'archive ouverte pluridisciplinaire HAL, est destinée au dépôt et à la diffusion de documents scientifiques de niveau recherche, publiés ou non, émanant des établissements d'enseignement et de recherche français ou étrangers, des laboratoires publics ou privés. 


\section{Accepted Manuscript}

Relationships among predatory fish, sea urchins and barrens in Mediterranean rocky reefs across a latitudinal gradient

P. Guidetti, J. Dulčić

PII:

S0141-1136(06)00175-9

DOI:

10.1016/j.marenvres.2006.08.002

Reference:

MERE 3064

To appear in:

Marine Environmental Research

Received Date: $\quad 17$ November 2005

Revised Date: $\quad 4$ August 2006

Accepted Date: $\quad 8$ August 2006

Please cite this article as: Guidetti, P., Dulčić, J., Relationships among predatory fish, sea urchins and barrens in Mediterranean rocky reefs across a latitudinal gradient, Marine Environmental Research (2006), doi: 10.1016/ j.marenvres.2006.08.002

This is a PDF file of an unedited manuscript that has been accepted for publication. As a service to our customers we are providing this early version of the manuscript. The manuscript will undergo copyediting, typesetting, and review of the resulting proof before it is published in its final form. Please note that during the production process errors may be discovered which could affect the content, and all legal disclaimers that apply to the journal pertain. 
Relationships among predatory fish, sea urchins and barrens in Mediterranean rocky reefs across a latitudinal gradient

\author{
P. Guidetti ${ }^{1, *}$, J. Dulčić ${ }^{2}$ \\ ${ }^{1}$ Laboratory of Zoology and Marine Biology, DiSTeBA, University of Lecce, via prov.le \\ Monteroni, 73100 Lecce, Italy \\ ${ }^{2}$ Institute of Oceanography and Fisheries, POB 500, 21000 Split, Croatia
}

*Corresponding author.

E-mail address: paolo.guidetti@unile.it; Tel: +39/0832/298935; Fax: +39/0832/298626 


\section{Abstract}

Previous studies conducted on a local scale emphasised the potential of trophic cascades in Mediterranean rocky reefs (involving predatory fish, sea urchins and macroalgae) in affecting the transition between benthic communities dominated by erected macroalgae and barrens (i.e. bare rock with partial cover of encrusting algae). Distribution patterns of fish predators of sea urchins (Diplodus sargus sargus, D. vulgaris, Coris julis and Thalassoma pavo), sea urchins (Paracentrotus lividus and Arbacia lixula) and barrens, and fish predation rates upon sea urchins, were assessed in shallow (3-6 m depth) sublittoral rocky reefs in the northern, central and southern sectors of the eastern Adriatic Sea, i.e. on a large spatial scale of hundreds of kilometres. No dramatic differences were observed in predatory fish density across latitude, except for a lower density of small D. sargus sargus in the northern Adriatic and an increasing density of T. pavo from north to south. Paracentrotus lividus did not show any significant difference across latitude, whereas A. lixula was more abundant in the southern than in the central Adriatic. Barrens were more extended in the southern than in the central and northern sectors, and were related with sea urchin density. Fish predation upon adult sea urchins did not change on a large scale, whereas it was slightly higher in the southern sector for juveniles when predation rates of both urchins were pooled. Results show that: 1) assemblages of predatory fish and sea urchins, and barren extent change across latitude in the eastern Adriatic Sea, 2) the weak relations between predatory fish density and predation rates on urchins reveal that factors other than top-down control can be important over large scale (with the caveat that the study was conducted in fished areas) and 3) patterns of interaction among strongly interacting taxa could change on large spatial scales and the number of species involved.

Key words: Predatory fish; Sea urchins; Barrens; Top down; Coastal zone; Latitudinal gradients; Adriatic Sea. 


\section{Introduction}

Sea urchins are important grazers in marine subtidal communities in temperate regions (Sala et al., 1998 and references therein). When at high density, they can cause the transition from macroalgal forests to coralline barrens, i.e. bare rocks with encrusting algae (Tegner \& Dayton, 1981; McClanahan \& Shafir, 1990; Sala, Harmelin-Vivien \& Boudouresque, 1998), with repercussions for rocky-reef ecosystem structure and functioning (Sala et al., 1998). Predators can affect density, behavior and population structure of sea urchins (Tegner \& Dayton, 1981; McClanahan \& Shafir, 1990; Scheibling, 1996; Sala et al., 1998; Shears \& Babcock, 2002; Tuya, Boyra, Sanchez-Jerez, Barbera \& Haroun, 2004; Guidetti, 2006), which means they may indirectly influence the structure of benthic communities by mediating urchin grazing pressure (Shears \& Babcock, 2002).

Benthic communities in the shallow Mediterranean rocky sublittoral range from coralline barrens (dominated by sea urchins and encrusting algae) to diverse macroalgal beds (which harbour hundreds of species of algae and invertebrates). The sea urchins Paracentrotus lividus and Arbacia lixula (that may coexist in rocky reefs; Bulleri, Benedetti-Cecchi \& Cinelli, 1999) can cause the transition between these two community states (Sala et al., 1998; Boudouresque \& Verlaque, 2001; see also Bulleri, Bertocci \& Micheli, 2002). The sea breams Diplodus sargus sargus and D. vulgaris (actively preying upon juvenile and adult sea urchins) and largesized individuals of the wrasses Coris julis and Thalassoma pavo (preying upon urchins $<1 \mathrm{~cm}$ in test diameter) are the only predators that may effectively prey upon sea urchins (Sala, 1997; Sala et al., 1998; Guidetti, 2004; Hereu, Zabala, Linares \& Sala, 2005).

The available studies about the relationships between predatory fish, sea urchins and macroalgae in the Mediterranean Sea chiefly took into account P. lividus (e.g. Verlaque, 1987; Sala \& Zabala, 1996; Sala et al., 1998), but there is increasing evidence that A. lixula may exert an important role (Guidetti, Fraschetti, Terlizzi \& Boero, 2003; Micheli, Benedetti-Cecchi, 
Gambaccini, Bertocci, Borsini, Osio et al., 2005). This sea urchin, in fact, is more effective in scraping rocky surfaces (Boudouresque \& Verlaque, 2001) and less impacted by predation (Guidetti \& Mori, 2005; Guidetti, 2006). Predation upon sea urchins is generally higher where predatory fish are abundant and large (e.g. within MPAs; Sala \& Zabala, 1996; Guidetti, 2006), but, on the other hand, the patterns observed are not obvious (Guidetti \& Sala, unpubl. data), nor consistent in time or at large spatial scale (Sala et al., 1998; Guidetti, 2006; Guidetti, Bussotti \& Boero, 2005; Micheli et al., 2005). Latitudinal differences in the diversity of assemblages of predator and prey species may affect the way strongly interacting taxa (e.g. fish and urchins) interact (Tegner \& Dayton, 2000; Steneck, Graham, Bourque, Corbett, Erlandson, Estes et al., 2002). No previous studies were done, however, that investigated the relationships among predator fish, sea urchins and barrens in the Mediterranean Sea across latitude. Such knowledge, however, is necessary for predicting the consequences of the ongoing large-scale changes in the distribution patterns of thermophilous species through the Mediterranean Sea (including e.g. T. pavo and A. lixula; Francour, Boudouresque, Harmelin, Harmelin-Vivien \& Quignard, 1994; Guidetti, Bianchi, La Mesa, Modena, Morri, Sara et al., 2002; Dulčić, 2003) as a response to seawater warming (Astraldi, Bianchi, Gasparini \& Morri, 1994; Dulčić \& Grbec, 2000; Dulčić, Grbec, Lipej, Beg Paklar, Supić \& Smirčić, 2004), which could have potential wide-community effects.

This study, therefore, aims at assessing the relationships between predatory fish, sea urchins and barrens in sublittoral rocky reefs across a latitudinal gradient in the eastern Adriatic Sea.

\section{Materials and methods}

\subsection{Study area}

This study was done along the eastern Adriatic coast, from Trieste (northern Adriatic Sea; NE Italy) to Dubrovnik (southern Adriatic Sea; southern Croatia) (Fig. 1). Climatic 
conditions markedly change along this latitudinal gradient (e.g. lowest sea water temperature and salinity decrease from south to north; Gačić, Civitarese \& Ursella, 1999; Dulčić \& Grbec, 2000). Three sectors, i.e. northern, central and southern Adriatic Sea, were arbitrarily chosen across latitude and sampled in late summer-early autumn 2004: two locations (situated 80-130 $\mathrm{km}$ apart from each other; Trieste and Rovinj in the northern Adriatic; Zadar and Split in the central Adriatic; around Makarska and Dubrovnik in the southern Adriatic; Fig. 1) were randomly selected within each of the three sectors, with three random sites (located $5-20 \mathrm{~km}$ apart from each other) sampled within each location. The assessment of distribution patterns of predatory fish, sea urchins and barrens, and the experimental evaluation of fish predation intensity on sea urchins were done in shallow (3-6 m depth) rocky reefs. This depth was chosen because it was common to all sites and locations studied.

\subsection{Distribution patterns of predatory fish, sea urchins and barrens}

Predatory fish density was assessed by visual census along 25 x 5 m transects (HarmelinVivien, Harmelin, Chauvet, Duval, Galzin, Lejeune et al., 1985). Ten transects (i.e. replicates) were done at each site within location and sector (for a total of 180 censuses). Settlers and recruits $(<2 \mathrm{~cm}$ total length, TL) were excluded from the study as their numerical contribution may greatly influence mean density values, while having no predatory effect on sea urchins. Only large-sized Coris julis and Thalassoma pavo (> 2/3 of maximum size that equals $25 \mathrm{~cm}$ TL; Fischer, Bauchot \& Schneider, 1987) were included in the analysis as they are the only wrasses able to effectively prey upon sea urchins. Small-sized Diplodus sargus sargus and D. vulgaris $(<33 \%$ of the maximum size of $45 \mathrm{~cm}$ TL; Fischer, Bauchot \& Schneider, 1987) were treated separately from adults (i.e. fish $>33 \%$ of maximum size). Small Diplodus, in fact, prey only upon juvenile sea urchins, while adult Diplodus eat juveniles, medium- and, to a lesser extent, large-sized sea urchins (Sala 1997; Guidetti 2004, 2006). 
Counts of sea urchins were done within quadrats of $1 \mathrm{~m}^{2}$ (20 replicates) at each sector, location and site (for a total of 360 counts). This method is suitable for assessing the adult (>1 $\mathrm{cm}$ in diameter) fraction of sea urchin populations (Sala \& Zabala, 1996). Care was taken to look for urchins into crevices and under boulders. Sampling of Paracentrotus lividus and Arbacia lixula was made by separate series of quadrats to insure independence of data.

Percent cover of barrens was evaluated using quadrats of $1 \mathrm{~m}^{2}(\mathrm{n}=20)$ at each sector, location and site (for a total of 360 samples). Each sample consisted of superimposing a quadrat with a grid of 25 small squares (each representing $4 \%$ of the quadrat). The extent of barrens was quantified according to Dethier et al. (1993) and Guidetti (2006, and references therein).

\subsection{Fish predation impact on adult and juvenile sea urchins}

Predation intensity upon adult urchins was estimated using tethering (Sala \& Zabala, 1996; Shears \& Babcock, 2002) carried out directly in the field. Tethering involved inserting a thin nylon filament $(0.25 \mathrm{~mm}$ diameter $) \sim 50 \mathrm{~cm}$ long, by means of a thin needle, through the dorsal and ventral surface of each urchin test, as far away from the oral-aboral axis as possible. Each experimental unit (EU) was formed by ten sea urchins tied by means of thin monofilaments to a main thick nylon monofilament (1.0 mm diameter) 8-10 m long. Separate EUs were made for each species of urchin (Paracentrotus lividus and Arbacia lixula), and for each of two size classes considered (medium: $2-3.5 \mathrm{~cm}$ in test diameter without spines; large: $>3.5 \mathrm{~cm}$; Guidetti, 2006). Laboratory trials and previous studies (e.g. Shears \& Babcock, 2002 and references therein) revealed low mortality due to tethering, except for sea urchins $<2 \mathrm{~cm}$, not included in the experiment. Replicate EUs ( $n=3)$, therefore, consisted of ten tethered urchins for each single species and each size class placed at each site, location and sector (for a total of 216 EUs). The percentage of urchin tests missing (but remains were often close to the EUs) or 
opened in the latero-ventral part (typically attacked by Diplodus fish) was assessed 5 days later (Sala \& Zabala, 1996; Guidetti, 2006). None of the dead individuals still tied to the EUs had its test intact.

Predation intensity on juvenile urchins was assessed using urchins $0.5-1.0 \mathrm{~cm}$ in diameter, carefully collected with tweezers, and put into experimental arenas (EAs) formed by artificial grass bands delimiting a $1 \mathrm{~m}^{2}$ quadrat of rock without crevices where small urchins could conceal. Laboratory trials in aquaria showed that juvenile urchins do not cross such bands. Replicate EAs $(n=5)$ with ten juveniles of each species of sea urchin were made at each sector, location and site (for a total of 180 EAs). Each EA was watched for some minutes after preparation to check for possible attraction of fish caused by the diver; then the diver moved away, but EAs remained in sight or visible to the diver. About 20 min later the number of juvenile urchins still present within each EA was counted (see also Hereu et al. 2005).

Estimates of predation obtained by tethering and EAs are to be considered as measures of the predation potential (Sala \& Zabala, 1996; Shears \& Babcock, 2002; see also Barbeau \& Scheibling, 1994 and Aronson, Heck \& Valentine, 2001 for further discussion about tethering). On the whole, the experiments were completed within 2 weeks.

\subsection{Statistical treatment of data}

Analysis of variance (ANOVA; GMAV5 package, University of Sydney) was used to test for differences in predatory fish density (small Diplodus sargus sargus and D. vulgaris; adult D. sargus sargus and D. vulgaris; large Coris julis and Thalassoma pavo), sea urchin density (Paracentrotus lividus and Arbacia lixula) and percent extent of barrens 'among sectors', 'between locations' and 'among sites'. The factor 'Sector' (Se; 3 levels: northern, central, and southern Adriatic Sea) was fixed, 'Location' (Lo; 2 levels) was random and nested within 'Sector', and 'Site' (Si; 3 levels) was random and nested within 'Location'. 
ANOVA was also used to analyze predation intensity upon adult and juvenile sea urchins. With regard to predation intensity upon adult $P$. lividus, we first tested for possible differences among sectors, locations, and sites, and between size classes. The factors $S e, L o$ and $S i$ were treated as reported above; 'Size class' ( $S c$; 2 levels: medium vs large) was considered as fixed and orthogonal. As A. lixula was not found in the three northernmost locations (see Results), we tested for possible differences in the predation intensity between species $(S p ; 2$ levels: $P$. lividus vs A. lixula), size classes, among locations (considering only the three southernmost locations where the two species coexist) and sites. The factors $L o$ was random, $S i$ was random and nested in $L o$, while $S p$ and $S c$ were fixed and orthogonal.

Predation intensity on juvenile sea urchins was evaluated following the same criteria used for adult sea urchins, without considering, obviously, the factor 'size class'.

Prior to analysis, homogeneity of variance was tested by Cochran's test and, whenever necessary, data were appropriately transformed (Underwood, 1997). If transformations did not produce homogeneous variances, ANOVA was used on non-transformed data after setting $\alpha=$ 0.01 to compensate for the increased likelihood of Type I error. SNK test was used for posthoc comparisons, when appropriate (Underwood, 1997).

Relationships between relevant variables (e.g. barren extent and sea urchin density, predation intensity and predatory fish density) averaged within each study site were examined by correlation analysis.

\section{Results}

\subsection{Distribution patterns of predatory fish, sea urchins and barrens}

Assessment of the variability in the distribution patterns of predatory fishes, sea urchins and barrens at the different scales investigated is reported in Tables 1 and 2.

Density of small Diplodus sargus sargus was significantly higher in the central and 
southern sectors than in the northern Adriatic (Fig. 2a), while density of adults did not change among sectors (Fig. 2b). Density of small and adult D. vulgaris, and of large Coris julis did not change along the latitudinal gradient (i.e. among sectors; Fig. 3a, b; Fig. 4a). Although the inspection of the graph would suggest a lower density of $C$. julis in the northern sector (it was absent at Trieste), the significant variability among locations and sites is likely to have masked the differences among sectors. Density of large Thalassoma pavo was higher in the southern Adriatic than in the central sector, while the species was not recorded in the northern Adriatic (Fig. 4b).

Density of Paracentrotus lividus did not change among sectors (Fig. 5a). Density of Arbacia lixula was higher in the southern Adriatic than in the central sector, while the species was not recorded in the northern Adriatic (Fig. 5b).

Percent extent of barrens was significantly higher in the southern than in the northern and central Adriatic Sea, with no significant differences between these two latter sectors (Fig. 6).

Relationships between mean density of each sea urchin species (P. lividus and A. lixula) and the percent extent of barrens at each sampling site were both positive, but the correlation was less strict for $P$. than for A. lixula (Fig. 7a and b).

\subsection{Fish predation intensity on adult and juvenile sea urchins.}

Predation upon adult Paracentrotus lividus did not change across latitude, and it was higher upon medium-sized than large-sized individuals at all locations, although the magnitude of the difference was not the same between locations within sector. ANOVA, moreover, revealed a significant interaction between 'size class' and 'location' (Sc x Lo(Se); Table 3, Fig. 8).

Predation intensity upon adult $P$. lividus and $A$. lixula at the three locations where the two sea urchins coexist (i.e. Split, Makarska, Dubrovnik) differed 'between species', and such a difference was not the same for the two size classes considered (Table 4, Fig. 8). ANOVA 
detected, in fact, a significant interaction between the factors 'species' and 'size class' ( $\mathrm{Sp} \mathrm{x}$ Sc), and SNK tests revealed that, for both P. lividus and A. lixula, medium-sized individuals were subject to a significantly higher predation than large-sized individuals, but such a difference was greater for $P$. lividus than for A. lixula. Overall, medium-sized $P$. lividus showed the greatest predation intensity (Fig. 8).

Density of fish preying upon adult sea urchins (i.e. adult D. sargus sargus and D. vulgaris) and predation intensity upon both medium- and large-sized $P$. lividus and A. lixula were not significantly correlated (Fig. 9a, b, c, d).

Predation impact upon juvenile $P$. lividus did not show any significant difference across latitude in the eastern Adriatic, or at the scale of locations and sites (Table 5, Fig. 10). Predation intensity upon juvenile sea urchins at the three locations where P. lividus and Arbacia lixula coexist differed 'between species' (Table 6), and SNK test revealed that predation was significantly greater upon $P$. lividus than A. lixula (Fig. 10).

Predation intensity on juvenile $P$. lividus and density of predatory fish was not significantly correlated (Fig. 11a). Conversely the relationship between predation intensity upon juvenile $A$. lixula and density of predatory fish was positive and significant (Fig. 11b).

\section{Discussion}

Diplodus sargus sargus, D. vulgaris and Coris julis did not show any dramatic difference in density across latitude (except for a significantly lower density of small-sized $D$. sargus sargus in the northern Adriatic and the absence of adult $C$. julis only in the northernmost location, i.e. at Trieste). Thalassoma pavo, instead, showed a higher abundance in the southern Adriatic than in the central sector, and it was absent in the northern sector. The peculiar hydroclimatic conditions in the northern Adriatic, in particular the lowest seawater temperature during winter (Mosetti, 1988; Zore-Armanda, 1991), could be invoked to explain the absence of T. pavo 
(and in part of $C$. julis) in this area. This hypothesis is consistent with the ecological traits of $T$. pavo. This wrasse, in fact, is a typically thermophilic fish thriving in the southern and eastern Mediterranean Sea (Francour et al., 1994; Guidetti et al., 2002). Its distribution limits, however, are currently expanding northwards in the western Mediterranean and the Adriatic Seas (Guidetti et al., 2002; Dulčić, 2003 and references) as a response to the ongoing water warming (Astraldi et al., 1994; Dulčić \& Grbec, 2000). Parallel to this, the frequency of occurrence of $C$. julis has been recently found to increase in northern Croatia and Slovenia (Hanel, 2005; Lipej, pers. comm.), i.e. close to Trieste, where it could appear in a short time. No explanation can be provided, instead, to interpret the distribution of small-sized Diplodus as there are no data about temperature preferences of juvenile sea breams.

Paracentrotus lividus did not show any significant difference across latitude, whereas Arbacia lixula was significantly more abundant in the southern than in the central Adriatic and it was not recorded in the northern sector (although some specimens were observed at very shallow depth; Guidetti, pers. obs.). Total sea urchin density thus tended to increase from north to south, parallel to the barrens extent. Arbacia lixula is a thermophilic species (Kempf, 1962) which significantly increased in density in the NW Mediterranean in recent decades (Francour et al., 1994). The warm-water affinity of A. lixula, as for T. pavo, could explain the distribution patterns observed in the eastern Adriatic. Although these data suggest that the overall density of sea urchins is greater in the southern sector, there are records of population explosions and collapses in the northern Adriatic that may alternatively cause formation of large barrens or almost complete recolonization by erect macroalgae (Boudouresque \& Verlaque, 2001; Hanel, 2005). This suggests that rocky reef communities in this region may display a very large variability in time. In this study, however, the extent of barrens was found to be greater in the southern Adriatic, where total sea urchin density was highest. Although the relationship between barren extent and urchin density was generally positive, this pattern was more 
evident for A. lixula. This supports the hypothesis that A. lixula may play an important role in the process of formation and maintenance of barrens in the Mediterranean (Bulleri et al., 1999; Micheli et al., 2005). From this point of view, the current expansion of this sea urchin northwards in the Mediterranean could have the potential of inducing changes to coastal phytobenthos (see Francour et al., 1994) by enhancing, for instance, the chance of transition from macroalgal beds to barrens.

Predation intensity was significantly higher upon P. lividus than A. lixula, and greater upon medium-sized than large-sized urchins for both species, as also observed in the SW Adriatic Sea (Guidetti, 2006). Attachment tenacity, test robustness and spine length are greater in $A$. lixula than $P$. lividus, and positively related with urchin size for both species. Arbacia lixula (and in general large-sized urchins) could therefore be more resistant to fish predation (Guidetti \& Mori, 2005), which could suggests that the more abundant A. lixula (or the higher the $A$. lixula:P. lividus ratio within the urchin assemblage), the less predatory fish could be effective in controlling sea urchin density, with increasing effects of grazing on benthic communities.

Predation intensity upon juvenile and adult $P$. lividus did not vary significantly across latitude. Similarly, predation intensity upon both juvenile and adult of A. lixula did not differ among the locations where this species occurred. If total predation intensity on adult sea urchins (even pooling predation rates on $P$. lividus and $A$. lixula) did not change with latitude, for juveniles overall predation on urchins ( $P$. lividus plus $A$. lixula) tended to be slightly higher in the southern Adriatic Sea. Distribution patterns of fish, urchins and barrens, and related predation rates, did not match with a classic trophic cascade model (Sala et al., 1998). This suggests that trophic interactions within shallow rocky-reefs may change over large scale due to factors (e.g. urchin recruitment or mortality during early life-stages; Hereu, Zabala, Linares \& Sala, 2004, 2005) other than top-down control, which may result in different effects of predators on sea urchins and benthic communities (at least in the study area). 
The relationship between predatory fish density and levels of predation was significant only for juvenile A. lixula. The weak relationship between overall densities of predatory fish and adult sea urchin preys could be explained considering that predators such as Diplodus seem to be effective in controlling urchin populations when at densities exceeding 15-20 fish $100 \mathrm{~m}^{-2}$ (Guidetti \& Sala, unpubl. data). Along the investigated coast, where sampling was done in fished areas, this threshold has seldom been exceeded. Although habitat complexity and pressure of micropredators (e.g. polychaetes, crustaceans, starfishes) could also be important to control sea urchin density (Sala \& Zabala, 1996; Sala et al., 1998; Hereu et al., 2005), these outcomes may involve that only if marine protected areas (MPAs) were put in place there is the potential for predatory fish populations to increase in abundance and size, and for top-down control to become effective in affecting rocky-reef community structure. From this perspective, there is an increasing evidence suggesting that within MPAs there are clear symptoms of topdown control of predatory fishes on urchins and, indirectly, on benthic communities in sublittoral rocky reefs (Sala et al., 1998; Michieli et al., 2005; Gudetti, 2006 and references therein).

This study also suggests that there could be significant differences in the way predatory fishes and sea urchins interact in rocky reefs across latitude due to diversity of assemblages of predators and preys (i.e. in terms of species number and relative abundances of predatory fishes and sea urchins that change among sectors in the eastern Adriatic Sea). This possibly involves different consequences on benthic communities over large spatial scale, as observed in marine rocky intertidal and subtidal communities elsewhere (Paine, 1980; Fowler-Walker \& Connell, 2002; Steneck et al., 2002). We observed, in fact, that diversity of predatory fish and urchin assemblages ( 2 predatory fish and 1 urchin in the northernmost location; 4 fish predators and 2 urchins in the south) increased from north to south in the eastern Adriatic Sea, parallel to total sea urchin density and barren extent. Differences in consumer diversity may affect the 
strength of the relationships among the species involved in the cascade (Williams, Estes, Doak \& Springer, 2004) varying across a latitudinal gradient. The extent of barrens was higher where both urchins coexist (e.g. in the southern sector) than where only P. lividus was found (i.e. in the northern sector), which again suggests that $A$. lixula could be more important than, or could interact with $P$. lividus, in forming and maintaining barrens (see also Micheli et al., 2005). It is difficult, however, to draw conclusions about the effects of changing consumer diversity on the trophic cascade, as diversity is here confounded (sensu Underwood, 1997) with changing overall consumer density (see Benedetti-Cecchi, 2004 and references about components of diversity). We analyzed in this study only distribution patterns, while proper experiments are needed to test whether or not the observed patterns are consistent with the hypothesis that the greater diversity of predators and herbivores, the lower is the chance of realization of trophic cascades (see Steneck et al., 2002).

In conclusion, predatory fishes did not appear to have a top-down controlling impact on sea urchin abundance on the west coast of the Adriatic (there was no relationship between fish abundance and predation levels), and both fish and urchins (and barrens) were more abundant in the southern Adriatic. This suggests that other factors can be important in controlling the distribution of sea urchins across large spatial scale. However, the densities of predatory fish were generally below the critical density required to impact on urchin populations, and this has been shown to be the case in many areas which are fished compared to MPAs (Guidetti and Sala, unpubl. data). It is possible that if fish densities were higher (e.g. creating MPAs) there would have been a positive relationship with predation levels and clearer trophic effects. This study, finally, shows that the number and evenness of strongly interacting species involved in the trophic cascade may change across latitude and this may reflect into different patterns of species interaction and related effects on benthic communities. This poses new questions about the potential effects of human impacts like fishing (impacting on Diplodus fish or P. lividus; 
Sala et al., 1998; Guidetti, Terlizzi \& Boero, 2004; Guidetti, 2006) and climate changes (e.g. influencing A. lixula and T. pavo; Francour et al., 1994; Guidetti et al., 2002) in affecting diversity (structural and functional) of assemblages of fish predators and sea urchins, with potential effects on community structure of Mediterranean rocky reef ecosystems.

Acknowledgements. This study was conducted in the framework of the FIRB 2003-2005 (Biodiversity and community organization in different environmental contexts) and represents a contribution towards the aims of MARBEF, an EU Network of Excellence on 'Marine Biodiversity and Ecosystem Functioning' under EU-Framework Programme 6. PG benefited from a CNR (Italian National Centre for Research) fellowship in the framework of the “NATO-CNR senior fellowship programme 2002". Many thanks are due to R. E. Scheibling, F. Micheli and S. Bussotti for their useful suggestions on an early version of the manuscript.

\section{References}

Aronson RB, Heck Jr. KL, Valentine JF (2001) Measuring predation with tethering experiments. Mar Ecol Progr Ser 214:311-312

Astraldi M, Bianchi CN, Gasparini GP, Morri C (1994) Climatic fluctuations, current variability and marine species distribution: a case study in the Ligurian Sea (North-West Mediterranean). Oceanol Acta 18:139-149

Barbeau MA, Scheibling RE (1994) Procedural effects of prey tethering experiments: predation on juvenile scallops by crabs and sea stars. Mar Ecol Progr Ser 111:305-310

Benedetti-Cecchi L (2004) Increasing accuracy of causal inference in experimental analyses of biodiversity. Funct Ecol 18:761-768

Boudouresque CF, Verlaque M (2001) Ecology of Paracentrotus lividus. In: Lawrence JM (ed) Edible sea urchins: Biology and Ecology. Elsevier, Amsterdam, p 177-216 
Bulleri F, Benedetti-Cecchi L, Cinelli F (1999) Grazing by the sea urchins Arbacia lixula L. and Paracentrotus lividus Lam. in the Northwest Mediterranean. J Exp Mar Biol Ecol 241:81-95

Bulleri F, Bertocci I, Micheli F (2002) Interplay of encrusting coralline algae and sea urchins in maintaining alternative habitats. Mar Ecol Prog Ser 243:101-109

Dethier MN, Graham ES, Cohen S, Tear LM (1993) Visual versus random-point percent cover estimations: 'objective' is not always better. Mar Ecol Prog Ser 96:93-100

Dulčić J, Grbec B (2000) Climate change and Adriatic ichthyofauna. Fish Oceanogr, 9:187-191

Dulčić J (2003) Record of ornate wrasse Thalassoma pavo (Labridae) in the northern Adriatic Sea. Cybium 28:75-76

Dulčić J, Grbec B, Lipej L, Beg Paklar G, Supić N, Smirčić A (2004) The effect of the hemispheric climatic oscillations on the Adriatic ichthyofauna. Fres Environ Bull 13:293298

Fischer W, Bauchot ML, Schneider M (1987) Fiches FAO d'identification des éspèces pour les besoins de la peche. Méditerranée et Mer Noire. Zone 37. II. Vertebrés. FAO, Rome, 2:761-1530

Fowler-Walker MJ, Connell SD (2002) Opposing states of subtidal habitat across temperate Australia: consistency and predictability in kelp canopy-benthic associations. Mar Ecol Prog Ser 240: 49-56

Francour P, Boudouresque CF, Harmelin JG, Harmelin-Vivien ML, Quignard JP (1994) Are the Mediterranean waters becoming warmer? Information from biological indicators. Mar Poll Bull 28:523-536

Gačić M, Civitarese G, Ursella L (1999) Spatial and seasonal variability of water and biogeochemical fluxes in the Adriatic Sea. In : Malanotte-Rizzoli P, Eremeen VN (eds) The eastern Mediterranean as a laboratory for the assessment of contrasting ecosystems. 
Kluwer Academic Publisher, Dordrecht, p 335-357

Guidetti P (2004) Consumers of sea urchins, Paracentrotus lividus and Arbacia lixula, in shallow Mediterranean rocky reefs. Helgol Mar Res 58:110-116

Guidetti P, Bianchi CN, La Mesa G, Modena M, Morri C, Sara G, Vacchi M (2002) Abundance and size structure of Thalassoma pavo (Pisces: Labridae) in the western Mediterranean Sea: variability at different spatial scales. J Mar Biol Ass UK 82:495-500

Guidetti P, Fraschetti S, Terlizzi A, Boero F (2003) Distribution patters of sea urchins and barrens in shallow Mediterranean rocky reefs impacted by the illegal fishery of the rockboring mollusc Lithophaga lithophaga. Mar Biol 143:1135-1142

Guidetti P, Terlizzi A, Boero F (2004). Effects of the edible sea urchin, Paracentrotus lividus, fishery along the Apulian rocky coasts (SE Italy, Mediterranean Sea). Fish Res 66:287-297

Guidetti P, Bussotti S, Boero F (2005) Evaluating the effects of protection on fish predators and sea urchins in shallow artificial rocky habitats: a case study in the northern Adriatic Sea. Mar Environ Res 59:333-348

Guidetti P, Mori M (2005) Morpho-functional defences of Mediterranean sea urchins, Paracentrotus lividus and Arbacia lixula, against fish predators. Mar Biol 147:797-802

Guidetti P (2006) Marine reserves reestablish lost predatory interactions and cause community effects in rocky reefs. Ecol Appl 16:963-976

Hanel R (2005) Recovery of Fucacean associations and associated fish assemblages in the vicinity of Rovinj, Istrian coast, northern Adriatic Sea. Period Biol. 104:159-163

Harmelin-Vivien ML, Harmelin JG, Chauvet C, Duval C, Galzin R, Lejeune P, Barnabe G, Blanc F, Chevalier R, Duclerc J, Lasserre G (1985) Evaluation des peuplements et populations de poissons. Méthodes et problèmes. Rev Ecol (Terre Vie) 40:467-539

Hereu B, Zabala M, Linares C, Sala E (2004) Temporal and spatial variability in settlement of the sea urchin Paracentrotus lividus in the NW Mediterranean. Mar Biol 144:1011-1018 
Hereu B, Zabala M, Linares C, Sala E (2005) The effects of predator abundance and habitat structural complexity on survival of juvenile sea urchins. Mar Biol 146:293-299

Kempf M (1962) Recherche d'écologie comparée sur Paracentrotus lividus (Lmk.) et Arbacia lixula (L.). Rec Trav Stat Mar Endoume 25:47-116

McClanahan TR, Shafir SH (1990) Causes and consequences of sea urchin abundance and diversity in Kenyan coral reef lagoons. Oecologia 83:362-370

Micheli F, Benedetti-Cecchi L, Gambaccini S, Bertocci I, Borsini C, Osio GC, Romano F (2005) Alternate states, marine protected areas, and the structure of Mediterranean rockyreef assemblages. Ecol Monogr 75:81-102

Mosetti F (1988) Condizioni idrologiche della costiera triestina. Hydrores 6:19-38

Paine RT (1980) Food webs, linkage, interaction strength, and community infrastructure. J Anim Ecol 49:667-685

Sala E, Zabala M (1996) Fish predation and the structure of the sea urchin Paracentrotus lividus populations in the NW Mediterranean. Mar Ecol Progr Ser 140:71-81

Sala E (1997) Fish predators and scavengers of the sea urchin Paracentrotus lividus in protected areas of the north-west Mediterranean Sea. Mar Biol 129:531-539

Sala E, Boudouresque CF, Harmelin-Vivien ML (1998) Fishing, trophic cascades, and the structure of algal assemblages: evaluation of an old but untested paradigm. Oikos 82:425439

Scheibling RE (1996) The role of predation in regulating sea urchin populations in eastern Canada. Oceanol Acta 19:421-430

Shears NT, Babcock RC (2002) Marine reserves demonstrate top-down control of community structure on temperate reefs. Oecologia 132:131-142

Steneck RS, Graham MH, Bourque BJ, Corbett D, Erlandson JM, Estes JA, Tegner MJ (2002) Environ Cons 29:436-459 
Tegner MJ, Dayton PK (1981) Population structure, recruitment and mortality of two sea urchins (Strongylocentrotus franciscanus and S. purpuratus) in kelp forests. Mar Ecol Prog Ser 5:255-268

Tegner MJ, Dayton PK (2000) Ecosystem effects of fishing in kelp forest communities. ICES J Mar Sci 57:576-589

Tuya F, Boyra A, Sanchez-Jerez P, Barbera C, Haroun RJ (2004) Relationships between rockyreef fish assemblages, the sea urchin Diadema antillarum and macroalgae throughout the Canarian Archipelago. Mar Ecol Prog Ser 278:157-169

Underwood AJ (1997) Experiments in ecology: their logical design and interpretation using analysis of variance. Cambridge University Press, Cambridge

Verlaque M (1987) Relations entre Paracentrotus lividus (Lamarck) et le phytobenthos de Mediterranée occidentale. In: Boudouresque CF (ed) Colloque International sur Paracentrotus lividus et les oursins comestibles. GIS Posidonie publ., Marseille, p 5-36

Zore-Armanda M (1991) Natural characteristics and climatic changes of the Adriatic Sea. Acta Adriat 32:567-586

Williams TM, Estes J, Doak DF, Springer AM (2004) Killer appetites: assessing the role of predators in ecological communities. Ecology 85:3373-3384 
Table 1. ANOVA on density of fish predator of sea urchins among the 3 sectors, between 2 locations per sector, and among 3 sites per location.

\begin{tabular}{|c|c|c|c|c|c|c|c|c|c|c|c|c|}
\hline & & & & & & Diplodus sar & is sargus & & & & & \\
\hline & & & & & Small-s & sized & & Adults & & & & \\
\hline Source & of varic & tion & $\mathrm{df}$ & MS & $F$ & $P$ & MS & $F$ & & & & \\
\hline Sector & & & 2 & $\begin{array}{ll}4.38 \quad 1 \\
\end{array}$ & 10.82 & $0.04 *$ & 4.32 & 1.32 & & & & \\
\hline Locatio & n(Sectc & & 3 & 0.40 & 0.57 & 0.64 & 3.27 & $5.06 \quad 0.0$ & & & & \\
\hline Site(Lo & cation( & Sector)) & 12 & 0.71 & 3.23 & $0.0003 * * *$ & 0.65 & $2.74 \quad 0.00$ & & & & \\
\hline Residua & & & 162 & 0.22 & & & 0.23 & & & & & \\
\hline Significa & ce leve & $: * \mathrm{p}<0.0$ & $5 ; * * \mathrm{p}$ & $<0.01 ; * * ;$ & $* \mathrm{p}<0$ & 001. & & & & & & \\
\hline ...cont & nue & & & & & & & & & & & \\
\hline & & Dip & lodus & ulgaris & & & & Coris & & & $\overline{\text { alassoma }}$ & a pavo \\
\hline & Small-s & ized & & & Adu & & & & & & & \\
\hline MS & $F$ & $P$ & & MS & $F$ & $P$ & MS & $F$ & $P$ & MS & $F$ & $P$ \\
\hline 142.49 & 1.67 & 0.33 & & 254.45 & 0.80 & 0.53 & 10.07 & $7 \quad 2.28$ & 0.25 & 102.11 & 735.16 & $0.0001 * * *$ \\
\hline 85.35 & 5.17 & $0.02 *$ & & 319.88 & 3.43 & 0.06 & 4.42 & 11.86 & $0.0007 * * *$ & 0.14 & 0.02 & 0.99 \\
\hline 16.50 & 4.63 & $0.0001 *$ & & 93.32 & 7.54 & $0.0001 * * *$ & 0.37 & 3.92 & $0.0001 * * *$ & 6.74 & 13.33 & $0.0001 * * *$ \\
\hline 3.56 & & & & 12.38 & & & 0.09 & & & 0.51 & & \\
\hline
\end{tabular}


Table 2. ANOVA on density of sea urchins and percent extent of barrens among the 3 sectors, between 2 locations per sector, and among 3 sites per location.

\begin{tabular}{|c|c|c|c|c|c|c|c|c|c|c|}
\hline \multirow[b]{2}{*}{ Source of variation } & \multirow[b]{2}{*}{ df } & \multicolumn{3}{|c|}{ Paracentrotus lividus } & \multicolumn{3}{|c|}{ Arbacia lixula } & \multicolumn{3}{|c|}{ Barren } \\
\hline & & MS & $F$ & $P$ & MS & $F$ & $P$ & MS & $F$ & $P$ \\
\hline Sector & 2 & 11.14 & 5.59 & 0.10 & 202.81 & 36.34 & $0.008 * *$ & 6137.39 & 30.87 & $0.01 * *$ \\
\hline Location(Sector) & 3 & 1.99 & 1.67 & 0.23 & 5.58 & 5.46 & $0.012^{*}$ & 198.80 & 2.30 & 0.12 \\
\hline Site(Location(Sector)) & 12 & 1.19 & 4.05 & $0.0001 * * *$ & 1.02 & 0.68 & 0.77 & 86.37 & 1.51 & 0.12 \\
\hline Residual & 342 & 0.29 & & & 1.50 & & & 57.29 & & \\
\hline
\end{tabular}

Significance level: * $\mathrm{p}<0.05 ; * \mathrm{p}<0.01 ; * * \mathrm{p}<0.001$. 


\section{ACCEPTED MANUSCRIPT}

Table 3. ANOVA on fish predation intensity upon adult Paracentrotus lividus between 2 size classes (medium- and large-sized urchins), among the 3 sectors, between 2 locations per sector, and among 3 sites per location.

\begin{tabular}{lcccc}
\hline Source of variation & df & MS & $F$ & $P$ \\
\hline Size class & 1 & 13868.89 & 40.53 & $0.008^{* *}$ \\
Sector & 2 & 335.56 & 0.29 & 0.77 \\
Location(Sector) & 3 & 1151.11 & 24.67 & $0.0001 * * *$ \\
Site(Location(Sector)) & 12 & 46.67 & 0.32 & 0.98 \\
Size class $\times$ Sector & 2 & 148.89 & 0.44 & 0.68 \\
Sise class $\times$ Location(Sector) & 3 & 342.22 & 11.85 & $0.0007 * * *$ \\
Size class $\times$ Site $($ Location(Sector)) & 12 & 28.89 & 0.20 & 0.99 \\
Residual & 144 & 146.11 & & \\
Significance level: $* \mathrm{p}<0.05 ; * * \mathrm{p}<0.01 ; * * * \mathrm{p}<0.001$. & & & \\
\end{tabular}

Table 4. ANOVA on fish predation intensity upon adult sea urchins between the 2 species (Paracentrotus lividus and Arbacia lixula), between 2 size classes (medium and large), among 3 locations (Split, Makarska, Dubrovnik; see Methods), and among 3 sites per location.

\begin{tabular}{lcccc}
\hline Source of variation & df & MS & $F$ & $P$ \\
\hline Species & 1 & 4013.89 & 233.06 & $0.004^{* *}$ \\
Size class & 1 & 5445.00 & 66.67 & $0.015^{*}$ \\
Location & 2 & 43.89 & 0.54 & 0.61 \\
Site $($ Location) & 6 & 81.67 & 0.96 & 0.45 \\
Species $\times$ Size class & 1 & 1680.56 & 97.58 & $0.011^{*}$ \\
Species $\times$ Location & 2 & 17.22 & 0.58 & 0.59 \\
Species $\times$ Site(Location) & 6 & 29.44 & 0.35 & 0.91 \\
Size class $\times$ Location & 2 & 81.67 & 3.13 & 0.12 \\
Size class $\times$ Site(Location) & 6 & 26.11 & 0.31 & 0.93 \\
Species $\times$ Size class $\times$ Location & 2 & 17.22 & 0.69 & 0.54 \\
Species $\times$ Size class $\times$ Site $($ Location) & 6 & 25.00 & 0.29 & 0.94 \\
Residual & 144 & 85.00 & & \\
\hline
\end{tabular}

Significance level: $* \mathrm{p}<0.05 ; * * \mathrm{p}<0.01 ; * * * \mathrm{p}<0.001$. 
Table 5. ANOVA on fish predation intensity upon juvenile Paracentrotus lividus among the 3 sectors, between 2 locations per sector, and among 3 sites per location.

\begin{tabular}{lcccc}
\hline Source of variation & df & MS & $F$ & $P$ \\
\hline Sector & 2 & 130.00 & 1.21 & 0.41 \\
Location(Sector) & 3 & 107.78 & 3.34 & 0.06 \\
Site(Location(Sector)) & 12 & 32.22 & 0.10 & 0.99 \\
Residual & 72 & 314.44 & & \\
Significance level: * $\mathrm{p}<0.05 ; * * \mathrm{p}<0.01 ; * * * \mathrm{p}<0.001$. & &
\end{tabular}

Table 6. ANOVA on fish predation intensity upon juvenile sea urchins between the two species (Paracentrotus lividus and Arbacia lixula), among 3 locations (Split, Makarska, Dubrovnik; see Methods), and among 3 sites per location.

\begin{tabular}{lcccc}
\hline Source of variation & df & MS & $F$ & $P$ \\
\hline Species & 1 & 8217.78 & 58.24 & $0.017^{*}$ \\
Location & 2 & 34.44 & 0.63 & 0.56 \\
Site(Location) & 6 & 54.44 & 0.22 & 0.97 \\
Species $\times$ Location & 2 & 141.11 & 2.82 & 0.14 \\
Species $\times$ Site(Location) & 6 & 50.00 & 0.21 & 0.97 \\
Residual & 72 & 243.89 & & \\
\hline
\end{tabular}

Significance level: $* \mathrm{p}<0.05 ; * * \mathrm{p}<0.01 ; * * * \mathrm{p}<0.001$ 


\section{Figures}

Fig. 1. Sampling locations: Tr=Trieste, Ro=Rovinj (northern Adriatic); Za=Zadar, Sp=Split (central Adriatic); Ma=Makarska, Du=Dubrovnik (southern Adriatic) (see Methods).

Fig. 2. Mean ( \pm SE) density of small-sized (a) and adult (b) Diplodus sargus sargus at each location (with three sites sampled at each location; codes as in Fig. 1) and sector studied.

Fig. 3. Mean ( \pm SE) density of small-sized (a) and adult (b) Diplodus vulgaris at each location (with three sites sampled at each location; codes as in Fig. 1) and sector studied.

Fig. 4. Mean ( \pm SE) density of large-sized Coris julis (a) and Thalassoma pavo (b) at each location (with three sites sampled at each location; codes as in Fig. 1) and sector studied.

Fig. 5. Mean ( \pm SE) density of Paracentrotus lividus (a) and Arbacia lixula (b) at each location (with three sites sampled at each location; codes as in Fig. 1) and sector studied.

Fig. 6. Mean $( \pm \mathrm{SE})$ percent extent of barrens at each location (with three sites sampled at each location; codes as in Fig. 1) and sector studied.

Fig. 7. Relationships between sea urchin density (a: Paracentrotus lividus; b: Arbacia lixula) and the percent extent of barrens at the studied sites.

Fig. 8. Mean $( \pm$ SE) predation intensity on adult sea urchins in relation to size (medium and large) at each location studied ( $a, b$ and $c$ indicate the three random sites sampled at each of the six locations within each of the three sectors investigated; codes as in Fig. 1). The experiment was not done on A. lixula in the locations where it was absent.

Fig. 9. Relationships between density (no. ind. $125 \mathrm{~m}^{-2}$ ) of fish preying upon adult sea urchins and the levels of predation (\%) measured in the field (a: medium-sized Paracentrotus lividus; b: large-sized P. lividus; c: medium-sized Arbacia lixula; d: large-sized A. lixula).

Fig. 10. Predation impact on juvenile sea urchins (Paracentrotus lividus and Arbacia lixula) at each location (three sites sampled at each location; codes as in Fig. 1) and sector studied. The experiment was not done on A. lixula in the locations where it was absent. 


\section{ACCEPTED MANUSCRIPT}

Fig. 11. Relationships between density (no. ind. $125 \mathrm{~m}^{-2}$ ) of fish predators and the intensity of predation (\%) on juvenile urchins (a: Paracentrotus lividus; b: Arbacia lixula). 


\section{ACCEPTED MANUSCRIPT}

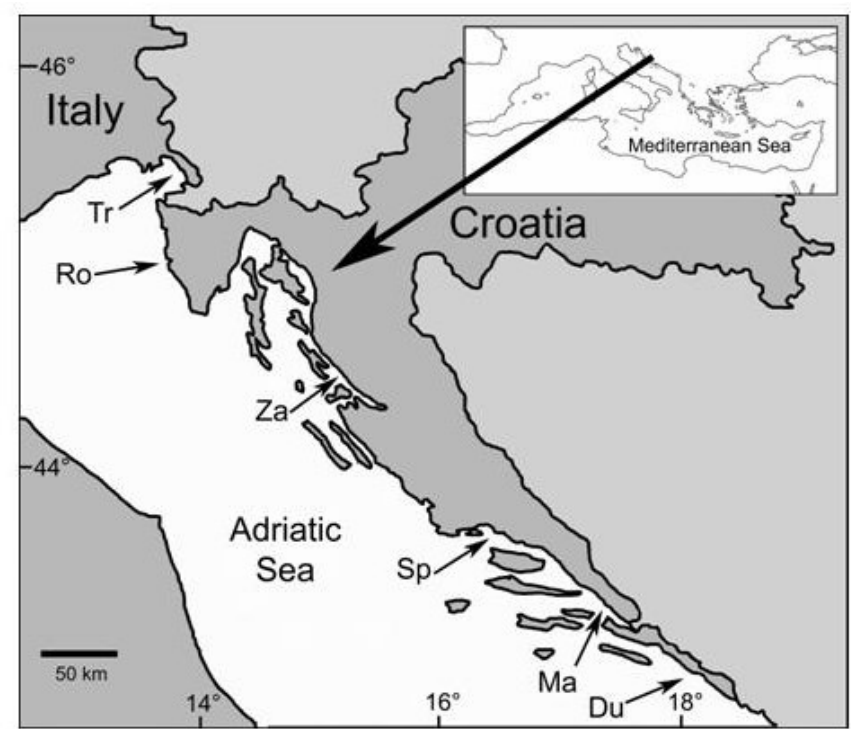

Fig. 1

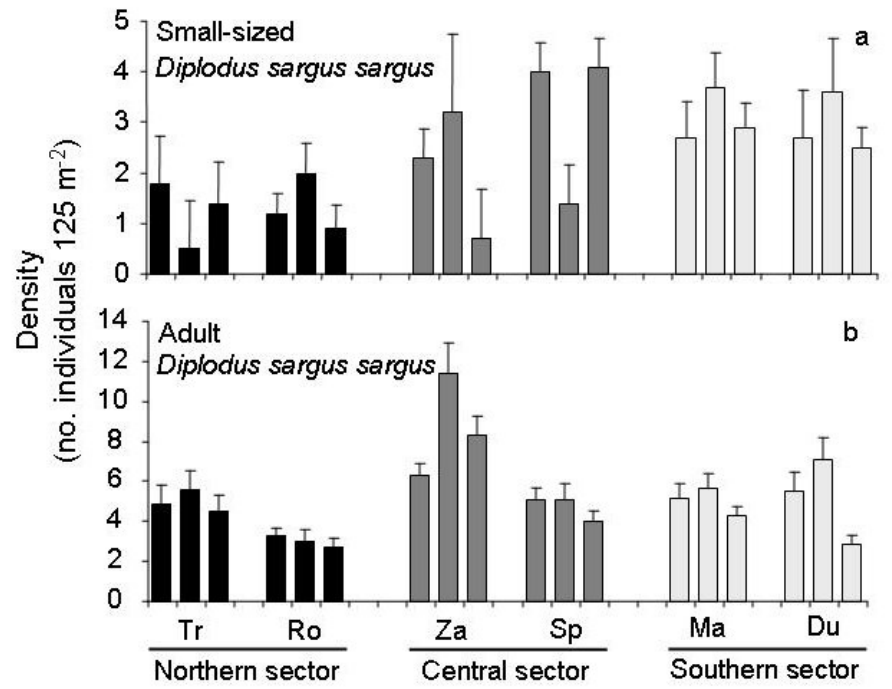

Fig. 2 


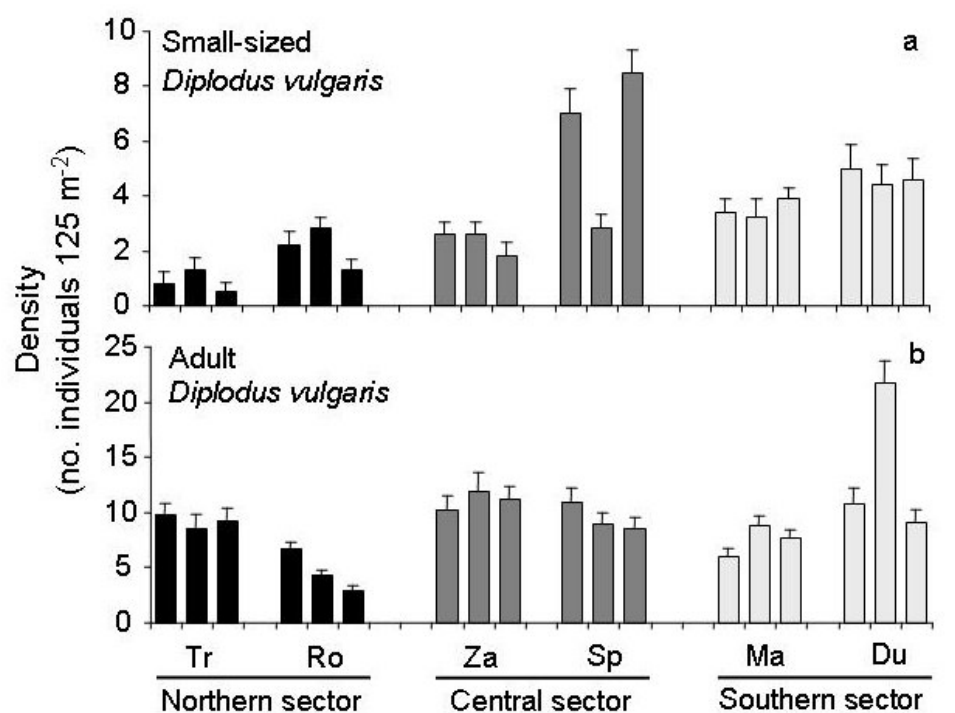

Fig. 3

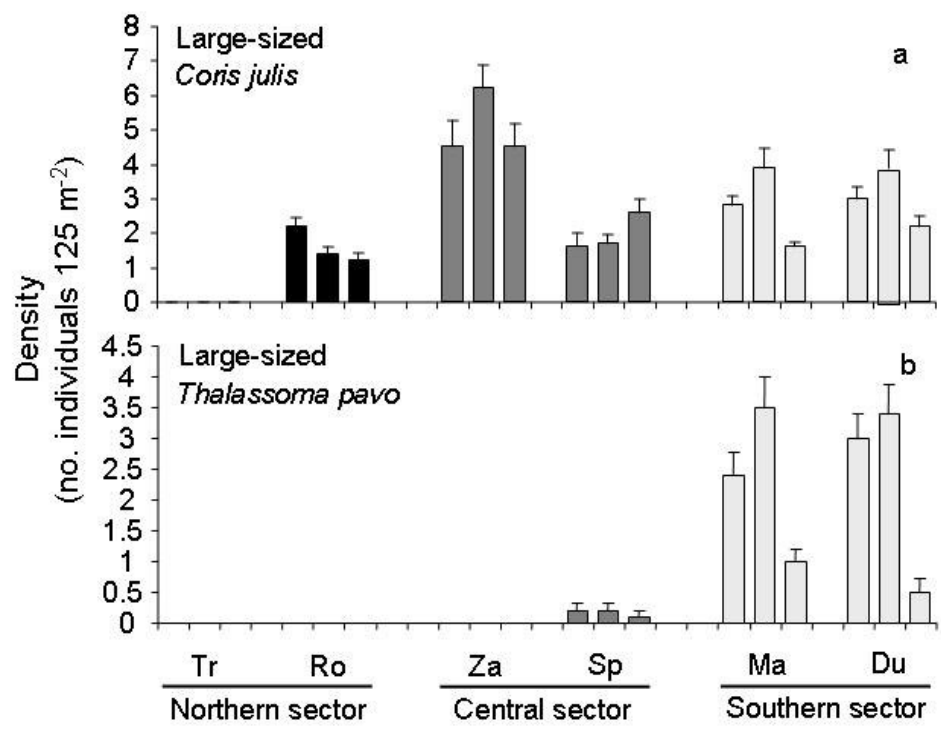

Fig. 4 


\section{ACCEPTED MANUSCRIPT}

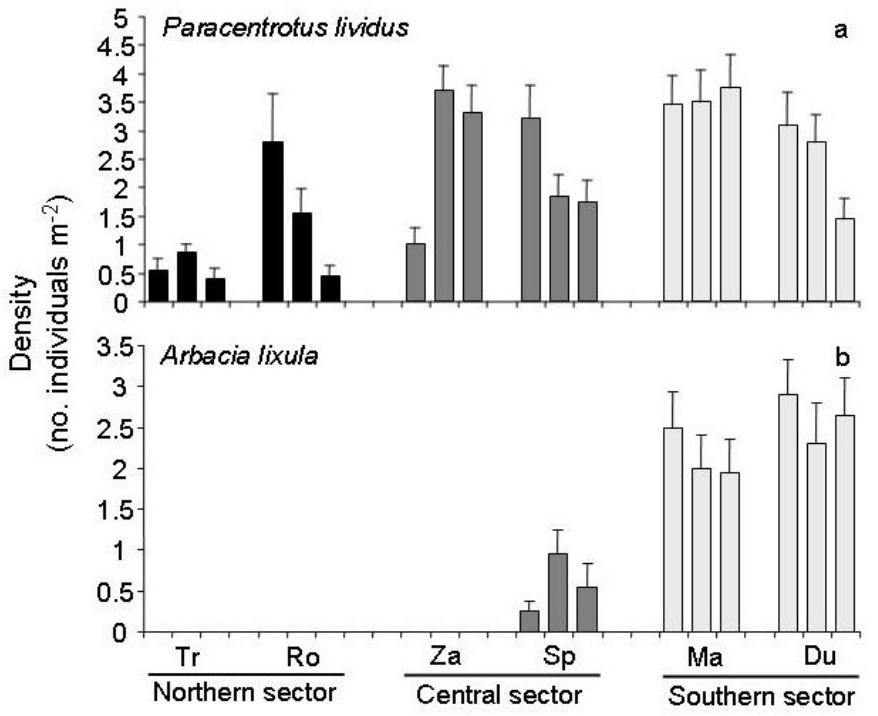

Fig. 5

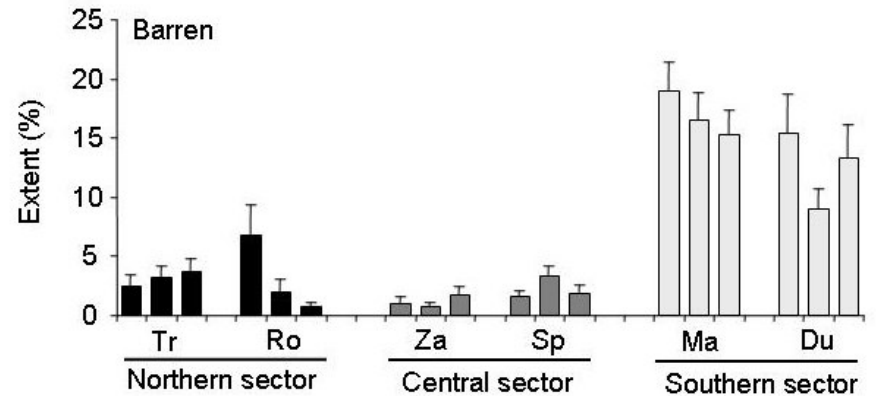

Fig. 6 


\section{ACCEPTED MANUSCRIPT}

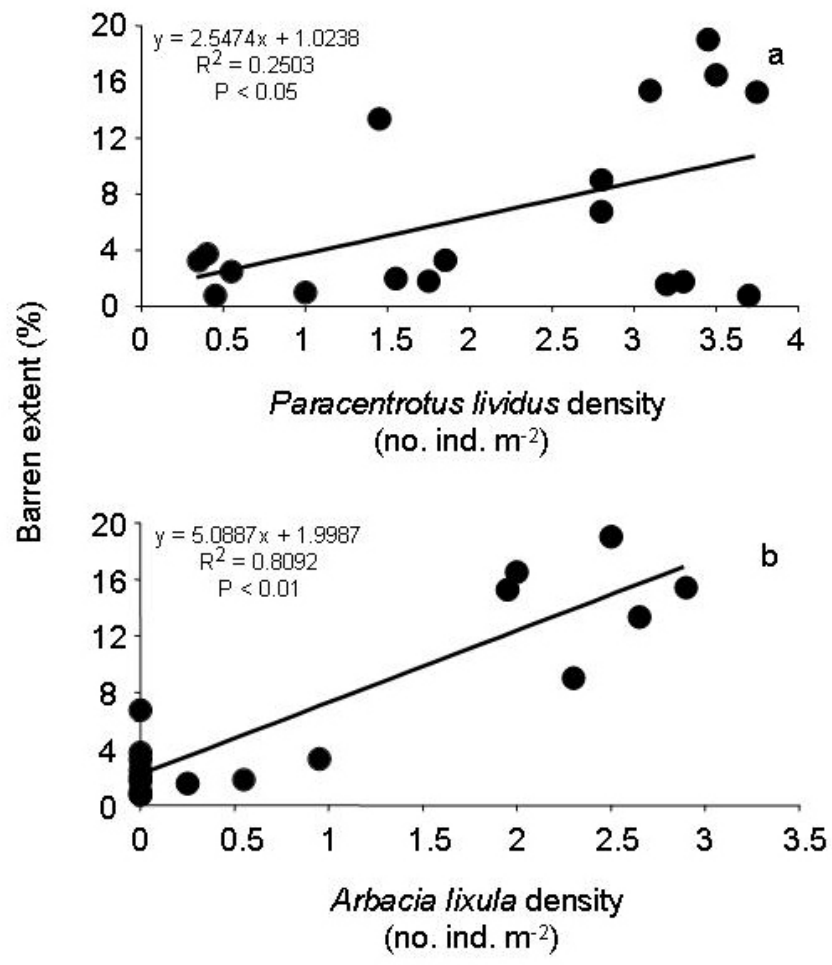

Fig. 7

Medium-sized Paracentrotus lividus

Medium-sized Arbacia lixula

Large-sized Paracentrotus /ividus

Large-sized Arbacia lixula

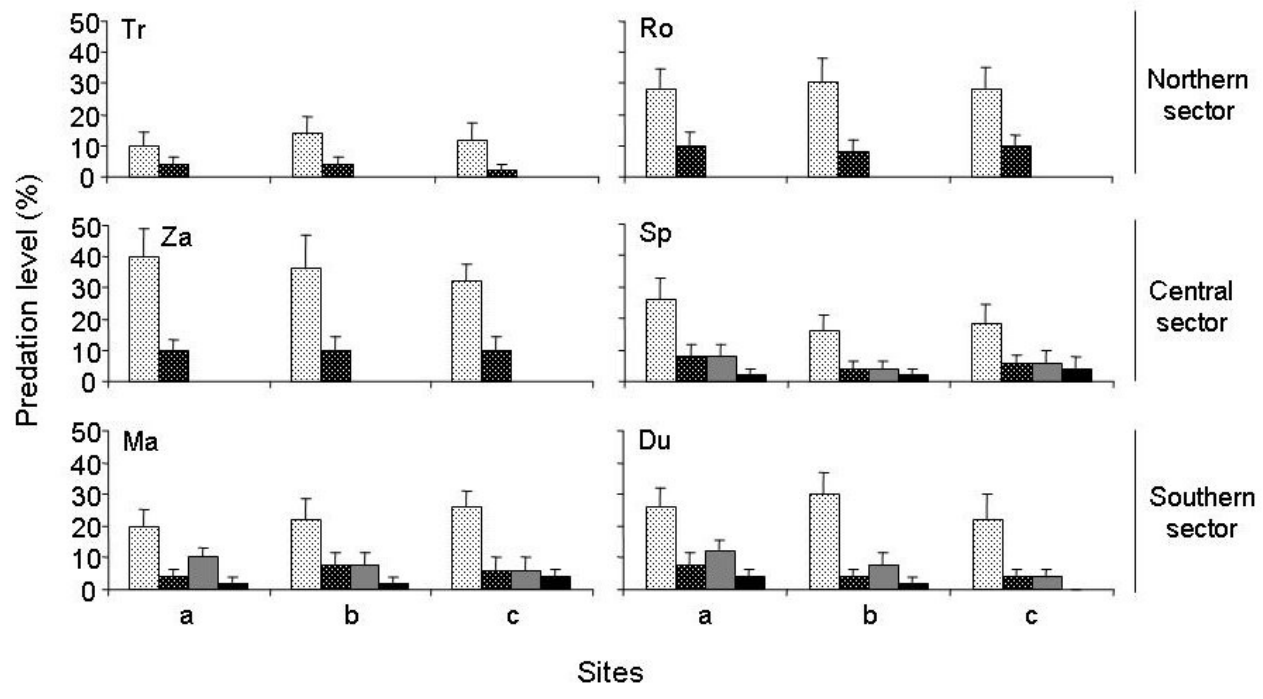

Fig. 8 

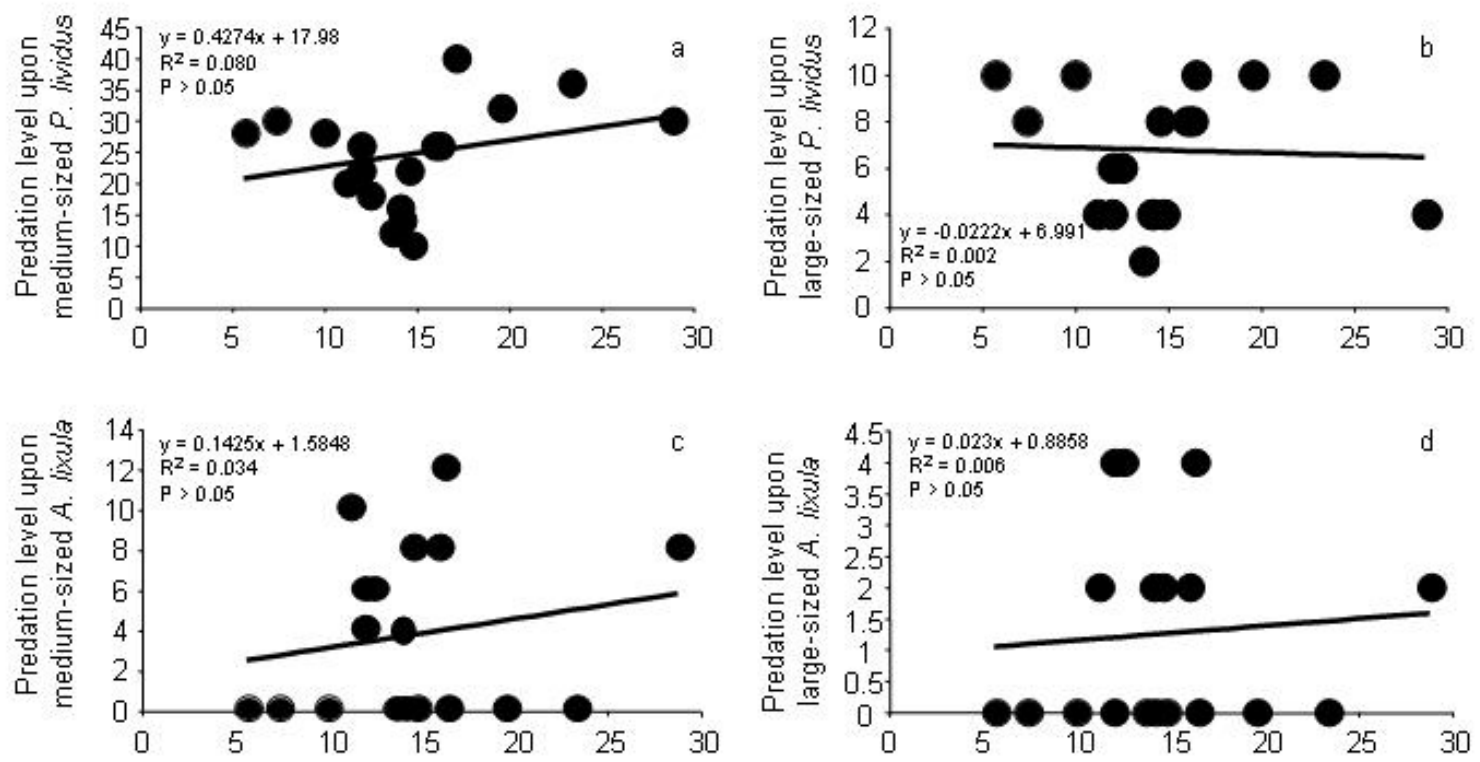

Density of fish predators of adult sea urchins

Fig. 9

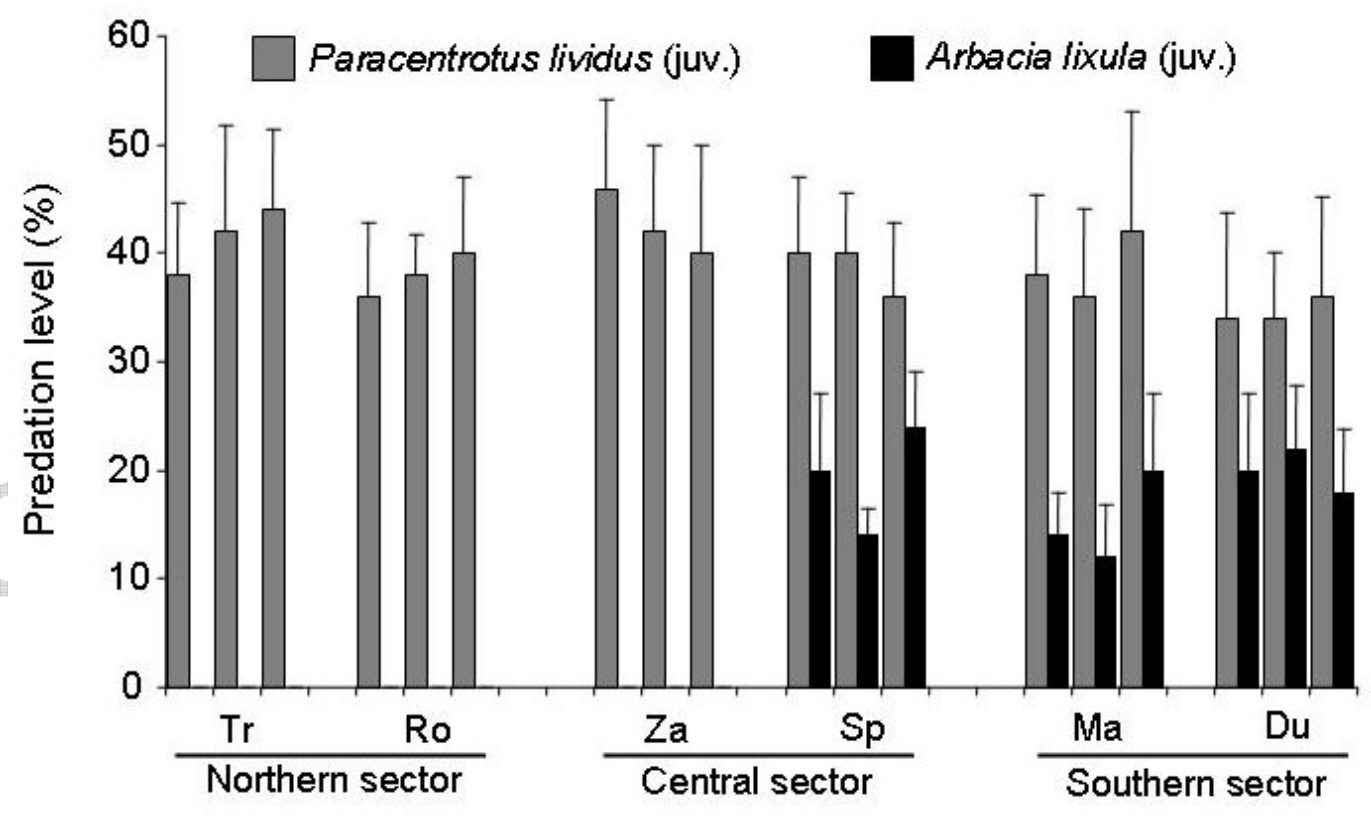

Fig. 10 


\section{ACCEPTED MANUSCRIPT}
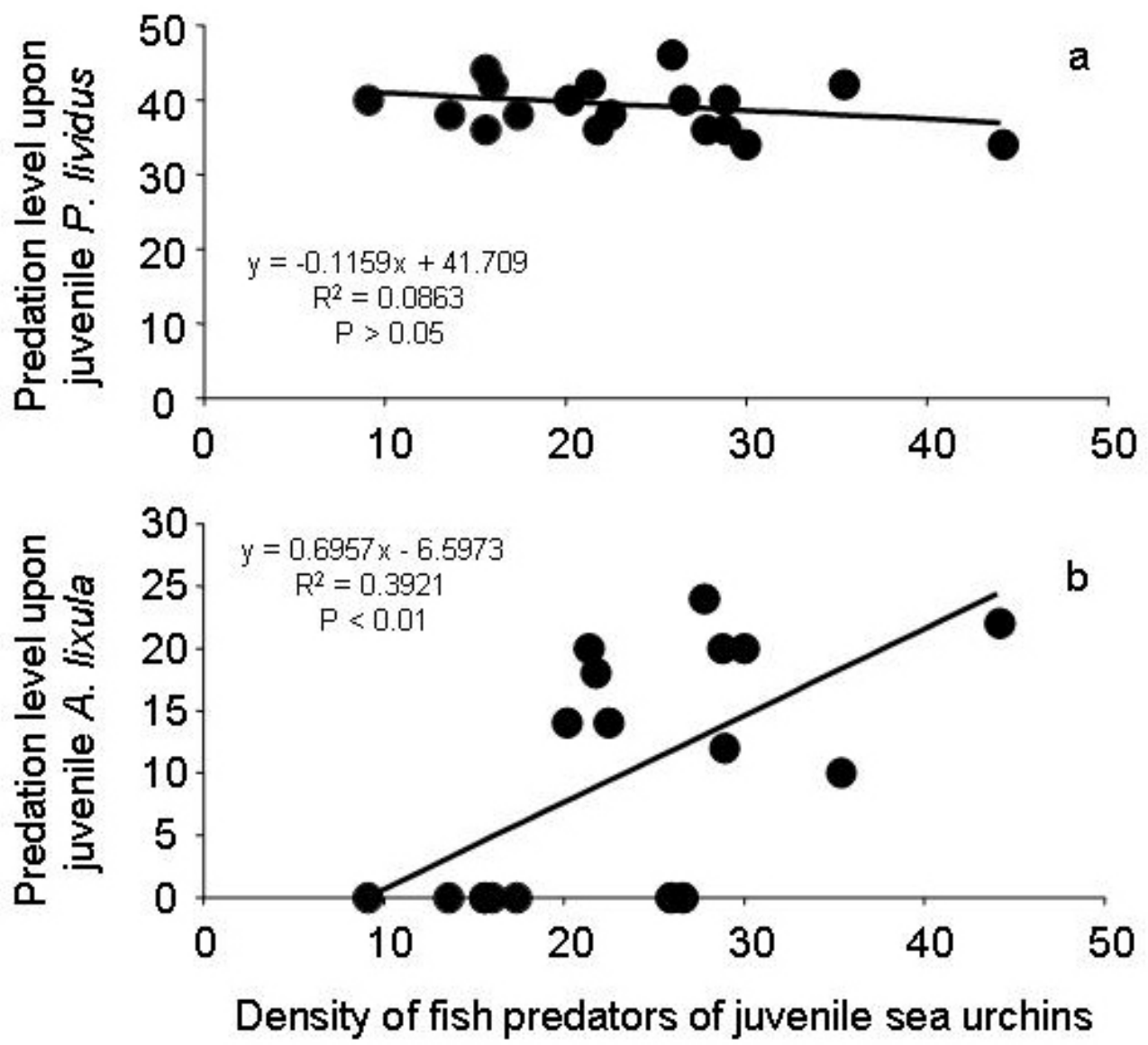

Fig. 11 